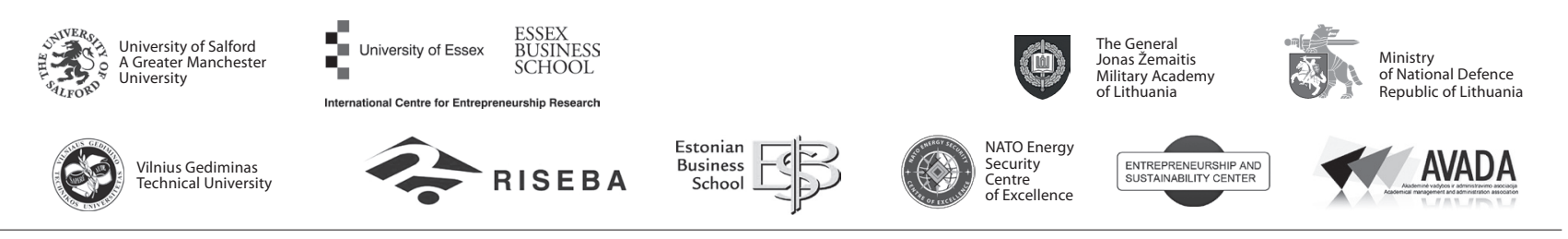

JOURNAL OF SECURITY AND SUSTAINABILITY ISSUES

ISSN 2029-7017 print/ISSN 2029-7025 online

2017 September Volume 7 Number 1

http://doi.org/10.9770/jssi.2017.6.4(13)

\title{
BUSINESS MODEL FOR A SEA COMMERCIAL PORT AS A WAY TO REACH SUSTAINABLE DEVELOPMENT GOALS
}

\author{
Vitalii Nitsenko ${ }^{1}$, Iryna Nyenno ${ }^{2}$, Irina Kryukova ${ }^{3}$, Tatyana Kalyna ${ }^{4}$, Mariia Plotnikova ${ }^{5}$ \\ ${ }^{1,2}$ Odessa I.I.Mechnikov National University, Ukraine \\ ${ }^{3}$ Odessa State Agrarian University, Ukraine \\ ${ }^{4}$ Odessa State Academy of Construction and Architecture, Ukraine \\ ${ }^{5}$ Zhytomyr National Agroecological University, Ukraine

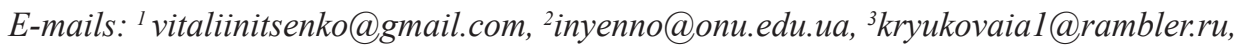 \\ ${ }^{4}$ tkalinka.zin@gmail.com,5mfplotnikova@gmail.com \\ Received 11 January 2017; accepted 27 July
}

\begin{abstract}
The aim of the article is to suggest a monitoring tool for a business model to assess performance and meet sustainable development goals and indicators for the sea commercial ports. According to the 2030 Sustainable Development Agenda, building resilient infrastructure, promoting inclusive and sustainable industrialization and fostering innovation is one of the seventeen goals set forward. We assume that added value is the key aim of any business model creation, while business model itself is recommended to be based on multidimensional innovation and complementary assets of business. The multidimensional innovations include: market innovation, product innovation and process innovation. The introduction part here presents the description of the business model development roadmap. For the specific case of a trade port case the business model rests on four blocks: the system for added value generation, value suggestion, clients and financial model. The complementary assets' list is presented for such a sea commercial port. Qualitative and quantitative indicators of the sea trade port business model performance are tracked down. Business model sustainable development for a sea commercial port is described. Value added is considered as the indicator of sustainable development on both micro- and macrolevels.
\end{abstract}

Keywords: business model, sustainable development goals, sustainable development indicators, added value, monitoring, ownership, commercial port

Reference to this paper should be made as follows: Nyenno, I., Nitsenko, V., 2017. Business model for a sea commercial port as a way to reach sustainable development goals, Journal of Security and Sustainability Issues 7 (5): 155-166.

http://dx.doi.org/10.9770/jssi.2016.7.1(13)

JEL Classifications: L22, L24, L25

\section{Introduction}

Sustainable development goal indicators were introduced as a global framework consisting of seventeen goals goals and targets by the expert interagency group back in 2015 (Progress, 2016; Urbaniec, 2015). Goal 9 encompasses three important aspects of sustainable development: infrastructure, industrialization and innovation. Infrastructure provides the basic physical systems and structures essential for operation of the society or enterprises. Industrialization drives economic growth, creates job opportunities and thereby reduces poverty. Innovation advances the technological capabilities of industrial sectors and promotes the development of new skills, as reported by the UN Secretary General (Report, 2016) in the first annual report on the topic. Business model concept is one of the main inventions for business structure and one of the principles of sustainable foundation (Bilan, 2013; Tvaronavičienè, Černevičiūtè, 2015.Streimikiene et al., 2016; Mukhtaro- 
va et al., 2016; Czyżewski et al., 2015; Simionescu et al., 2017; Čirjevskis, 2017; Hilkevics, Hilkevics, 2017).

Business model studies date back to the 1990s. Till nowadays the most influentional theories were built by Osterwalder (2010), Slywotzky (2006), Kim, Chan, and Mauborgne (2014). The range of authors consider the external impacts of economic environment on contemporary business models. Bossidi, Charan (2007), Bereznoy (2014), Soolyatte (2010) were studying the way to adapt a business model to changing environment and introduce it as an innovative one. The attention of such scientists as Chesbrough (2007), Schweizer (2005), Debelak (2006) has been focused on classification and evolution of approaches to business models as well as on future forecasting, as in (Zott, Amit, Massa, 2011). One of the still unsolved task is introduction of a more practical approach to business models' analysis.

The research is dedicated to the development of an experimental tool for assessing the functioning of a business model. A large number of today's studies focus on the description of structural elements of the business models. However, there is a lack of precision in assessing the aggregate and/or intermediate results of the the business model functioning. These works take into account, in particular, the hypothesis of Battocchio A., Minatogawa $\mathrm{V}$. in which they propose to combine the balanced system of indicators and a presentation method of the Kansas business model, thus leading to the construction of a roadmap. In a similar fashion, the authors suggest to build a tool for evaluating the financial structure of the business model. The business model is based on multidimensional innovation, the main purpose of its functioning is to create added value. Formation of a business model means not only unification of its key elements, concentrated around a successful business idea. Important factors in the development of any business-model are the mechanisms, methods and models for monitoring its further functioning. The bulk of the research is devoted to business models' design, but not to the evaluation of the process of their operation. Therefore, the main research task here is developing an approach to monitoring the functioning of the business model.

To achieve this, a number of problems have been solved to answer the central research question - how to conduct a systematic evaluation of a business model, namely:

1. To form a roadmap for developing a business model.

2. To identify sources for value creation in the sea trade port.

3. To form a business model of the sea trade port taking into account the specifics of value added creation.

4. To present the approach to business model tracking in accordance with its financial structure using quantitative financial and economic indicators.

5. To develop a tool for business model tracking based on quality indicators. For this purpose, indicators will be associated with management tasks within the framework of the competitiveness model of the sea trade port and the impact of its sustainable development on the macroeconomic level.

\section{Roadmap of the business model}

The roadmap for developing a business-model is as follows:

1. Generation of business-ideas. The process of generation takes place on the components of the businessmodel.

2. Evaluation a business-idea. A typical evaluation report (see Figure 1) is a summary of the ideas; its short technical description; people who are behind the idea and their interests; novelty of the idea; vision of value: consumer and social benefits, for whom the valuable idea, the potential of the market, including the rough business model and cost-investment part; risk / cost analysis (what is needed in terms of attracting additional assets and what are the risks of their attraction). 


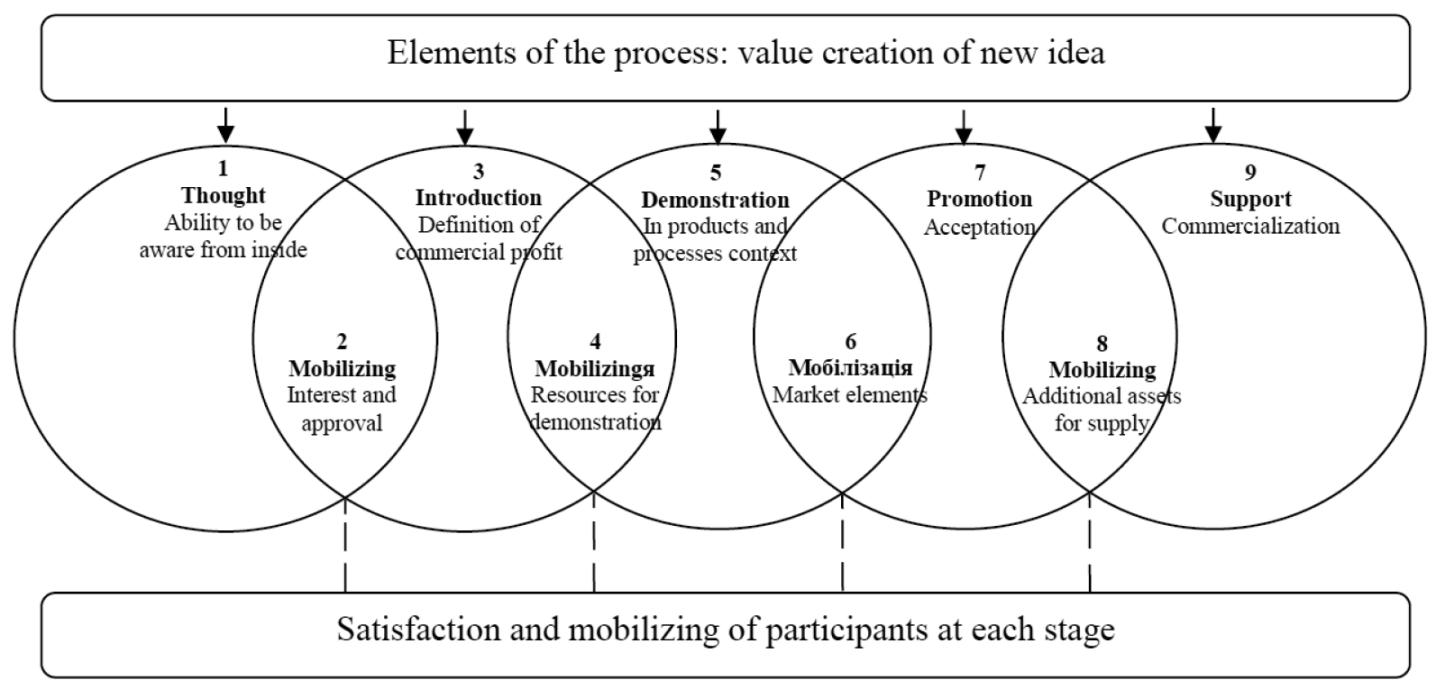

Fig. 1. Business-idea evauation algorythm

Source: own development.

The next steps that follow after evaluating an idea are checking its novelty, patent purity, the presence of market analogues, geographical constraints on the use of the idea, and other possible directions of development.

3. Business-model elements formation is presented on the figure 2 .

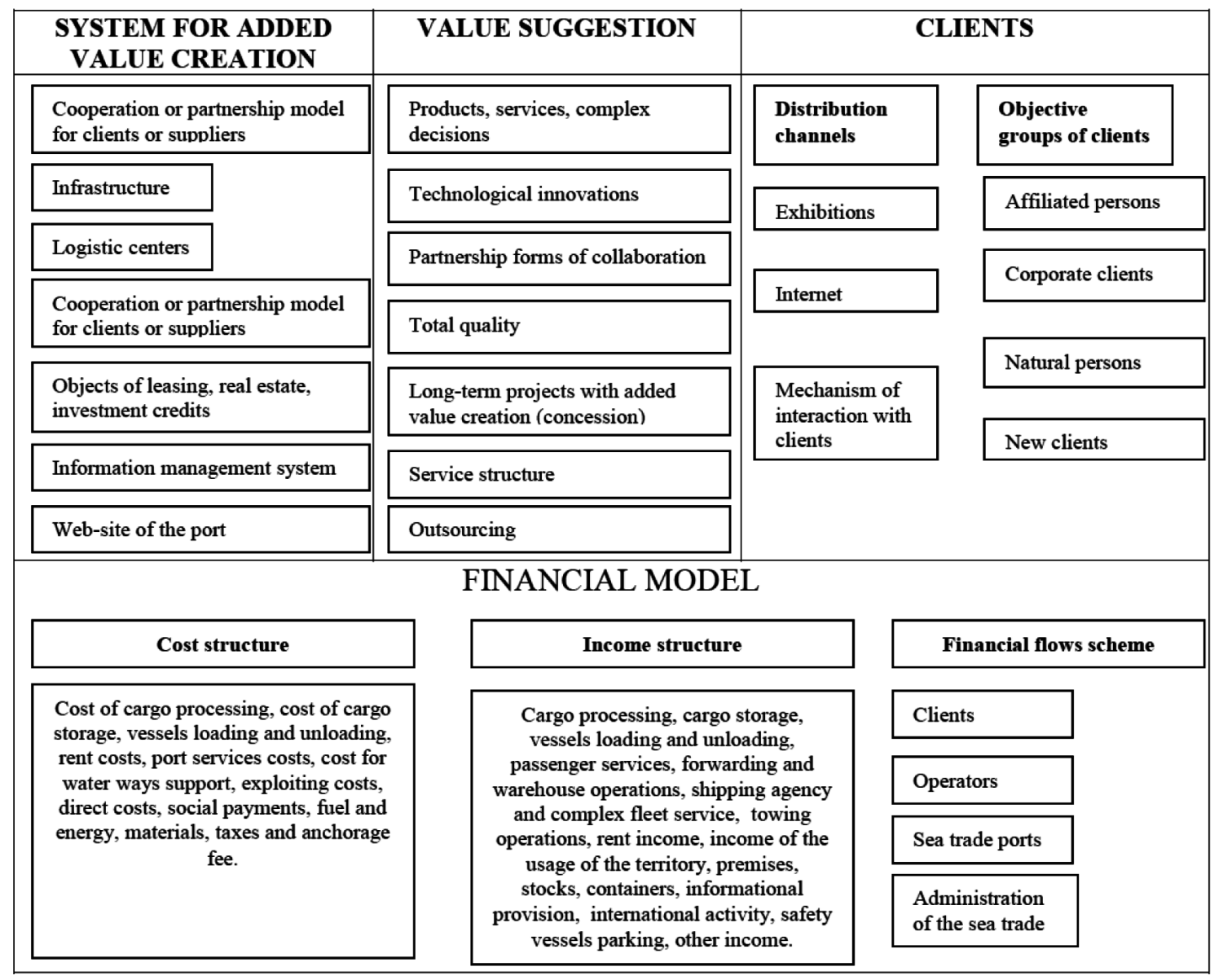

Fig. 2. Business-model visualization upon four blocks - Sea trade port case

Source: own development. 
Rothaermel, Hill Charles (2005) is concentrated in the technological discontinuities on the complementary assets perspective. Tripsas (1997) has made his input to prove the crucial role of the complementary assets while fighting the creative destruction. Pek-Hooi, Jiang (2010) described the complementary assets as a basis of business strategy. Abuzyarova (2015) describes the complementary assets as an effective tool for managing innovation projects. Buyanov (2014) uses the complementary assets for building the outsourcing model. While we are fixing the complementary assets as the basis of the business-model. The list of specialized complementary assets includes: reputation; brand; formed clusters; distribution network; specialists experience and qualification; expertise; sea port community; informative databases. Generic compelementary assets are: infrastructure; equipment; control and checkpoint capacities (customs control); computer and automatization systems; social networks, ERP-networks; agreements with the state and municipality. Dolzhenkova and Kazakova (2015) introduced complementary and synergic approach to the innovative development of the social-economic systems. While Pastor-Agustín, Ramírez-Alesón and Espitia-Escuer (2011) looked to the relation of the complementary assets and investment decisions.

4. Generation of business model innovation. The structural elements of multidimensional innovation are food innovation, market innovation, and innovation of the business model itself. Formation of a business-model in the form of multidimensional innovation, which includes: innovation in market definition for the establishment of categories of competitors, including producers of goods-substitutes; product or service innovation; the innovation of a business model as a result of the impact of market and product innovation, which leads to a change in the form of a business model (See Figure 3).

\begin{tabular}{|c|c|c|}
\hline \multicolumn{2}{|c|}{$\begin{array}{l}\text { Purpose of the business-model formation: } \\
\text { creation and keeping of the added value }\end{array}$} & \\
\hline $\begin{array}{l}\text { Directions } \\
\text { of the strategic decisions } \\
\text { of the business-model: } \\
\text {-customer segment choice; } \\
\text {-price proposal development; } \\
\text {-distribution channels } \\
\text { choice; } \\
\text { - customer relationships } \\
\text { building; } \\
\text { - income flows generating; } \\
\text { - key resources; } \\
\text { - key activity; } \\
\text { - key partnerships. }\end{array}$ & $\begin{array}{c}\text { Basis to form the } \\
\text { business-model: } \\
\text { MULTIDIMENSIONAL } \\
\text { INNOVATION } \\
\text { - market innovation; } \\
\text { - product innovation; } \\
\text { - business-model innovation } \\
\text { (process innovatio). } \\
\text { Tools to develop the } \\
\text { multidimensional } \\
\text { innovation: } \\
\text { technological brokerage; } \\
\text { technological audit. }\end{array}$ & $\begin{array}{l}\text { Operational activities to } \\
\text { use the multidimensional } \\
\text { innovations: } \\
\text {-identifying the opportunities } \\
\text { to spread one dimension to } \\
\text { another; } \\
\text {-establishing the connection } \\
\text { of innovation with the } \\
\text { created for consumers value; } \\
\text {-assessment of the } \\
\text { possibilities of increasing } \\
\text { added value as a source of } \\
\text { wage and investment } \\
\text { potential rise. }\end{array}$ \\
\hline
\end{tabular}

Fig. 3. Business-model formation through multidimensional innovation

Source: own development.

6. Creation of the added value of the business model.

\section{Value added in the sea trade port business-models}

R. L. M.Vleugels proposed three approaches to determining the impact of the port on the economy:

1. Added value. It is proposed to calculate the aggregate value added created by all the enterprises or branches associated with the port. For this purpose, the added value is taken into account as equal to the sum of wages and gross profits.

2. Analysis of costs and output. This approach requires detailed data that is difficult to obtain in some countries. 
3. Comparison of statistical data linking the port with the socio-economic well-being of the region (in particular, the share in GDP).

The sources of the added value generation are the process of manufacturing or providing services in the port. Generation of the added value in the ports of the fourth generation occurs in conditions of mixed cargo handling, complicated automation, complicated information, globalization of the port society and increased environmental control. Production characteristics are improved due to the emphasis on the quality of services, education of staff, while information technologies are becoming the decision-making factors. The business-model links the added value created through the commercialization of the market. There is a classification of ports according to their ownership or administration. The debate about the effectiveness of these forms attracts the attention of modern investors, government officials and academics. Typical port ownership forms are:

1) State property. It can be either full or partial.

2) Autonomous property, or management in the trust. This form of ownership was distributed before the privatization of the ports of Great Britain in the 1980's. Trust is a quasi-managerial form of organization. It is a non-profit organization that performs unified administration of the functions of the allocated territory. In this way, the problem of fund insufficiency and certain restrictions is solved.

3) Municipal ownership form used in Rotterdam, Hamburg, Kobe and Yokohama. This form has a basic advantage - meeting the needs of the port through local cooperation. The municipality may also decide on port subsidies, because through the provision of competitive tariffs at the port and the promotion of trade, the overall welfare of the region increases. The main disadvantage is the lack of incentives for participation in national programs. The name "municipality" can change the significance of the port from the influence of the city's image.

4) Ports of private property. Privatization may lead to redistribution of port property for new use, increase capital value of ports and stimulate the local economy. However, there are studies (Alderton, 2008), which indicate that expectations of significant competition, investment inflow and overall improvement in commercial efficiency are not the result of privatization.

5) The form of ownership of any modern port can be a combination of these four types. An example of the spread of this approach is Landlord, which in translation means the land feudal lord. In it the state owns land and approaches to the port, and it gives the terminals leasing stevedores. The state provides infrastructure, while the tenant is a superstructure (cranes, overload equipment). The port that provides both the infrastructure and the superstructure at the same time relates to the instrumental type of port (Alderton, 2008). Ports that provide not only infrastructure and superstructure, but also all types of ship and cargo services are known as Service Ports. Numerous state ports are now abandoning the service port model. However, it is known that this model was inherent to the port of Singapore until 1997, when it turned into a private company. At that time, the state port of Singapore was considered the most efficient port in the world. Today, the port authority is a widespread form of port control, which operates in accordance with their charter (see Table 1).

Table 1. Port authority responsibility

\begin{tabular}{|l|c|c|c|}
\hline \multicolumn{1}{|c|}{ Port type } & Infrastructure & Superstructure & Stevedoring \\
\hline Landlord & Yes & No & No \\
\hline Instrumental port & Yes & Yes & No \\
\hline Service port & Yes & Yes & Yes \\
\hline
\end{tabular}

Source: Alderton (2008).

Another alternative of management is contractual. It occurs when a private investor builds the capacity at the port, for some time operate on them and transfer it to the state in due time. This approach allows playing a very important role for private business in shaping and developing port facilities. An example is the Jawaharlal Nehru Port Trust Indian Port (JNPT), which signed an agreement to build a six hundred meter berth for container reloading for thirty years. 
Emerging countries implement a corporate or management contract method. In the case of the sale of land and superstructure in ports it is difficult to identify long-term sales advantages compared to the model of the "landlord", especially considering that such land will be sold at a low running price. An interesting alternative is the experience of the Sullom Voe harbor. Its owner is a city council, but the terminals are owned by thirty companies of the oil industry, which are operated by British Petroleum.

\section{Quantitative monitoring of the sea trade port business model}

Business-model of the company acts as a potential generator of cash flows, which affects the market value of the organization. At the same time, the company itself creates some internal factors of the model, the result of which is measured by the return on equity (Return On Equity, ROE). Therefore, on the basis of this indicator, you can analyze and assess the business-models of the company. Return on equity will be presented in the form of a three-factor model of DuPont (Du Pont model). Let's explain that this model represents an algorithm that forms the basis of DuPont system of financial analysis, according to which ROE is calculated as a ratio of net profit to equity. In this way, the ROE model will allow a detailed analysis of the financial and economic activity of the enterprise (see Table 2).

Table 2 Quantitative monitoring of the sea trade port business model, Ukraininan port Oktyabrsk, thous. UAH

\begin{tabular}{|c|l|c|c|c|c|}
\hline № & \multicolumn{1}{|c|}{ Indicator } & Abbreviation & 2014 & 2015 & 2016 \\
\hline 1 & Net sales income (for products, jobs, services) & NS & 249779 & 434874 & 395260 \\
\hline 2 & Gross profit & GP & 70658 & 235329 & 179601 \\
\hline 3 & Profit before taxation and credit payments & EBIT & 61510 & 229399 & 163545 \\
\hline 4 & Profit before taxation & PBT & 62322 & 230082 & 164058 \\
\hline 5 & Net profit & NP & 48191 & 187400 & 132236 \\
\hline 6 & Cash funds & CF & 62084 & 129671 & 87146 \\
\hline 7 & Receivables & R & 21990 & 18533 & 72440 \\
\hline 8 & Stocks & S & 17647 & 25737 & 21007 \\
\hline 9 & Other current assets & OCA & 903 & 636 & 827 \\
\hline 10 & Fixed assets & FA & 265194 & 282410 & 273082 \\
\hline 11 & Other non-current assets & LC & 7842 & 59623 & 84614 \\
\hline 12 & Loan capital & E & 343251 & 466466 & 489863 \\
\hline 13 & Equity & IFL & 32409 & 50144 & 52098 \\
\hline 14 & Interest-free liabilities & SCA & 0 & 0 \\
\hline
\end{tabular}

Source: Vashakmadze (2012).

Indicators and calculation formulas for the 12 factor decompositions of the return on equity are presented in Table 3.

Table 3. Twelve factors decomposition of the Rytorn on Equity (ROE) as a financial business-model structure

\begin{tabular}{|c|l|c|}
\hline № & \multicolumn{1}{|c|}{ Indicator } & Formula \\
\hline 1 & Gross margin,\% & GP / NS \\
\hline 2 & Effect from commercial and managerial costs & EBIT / GP \\
\hline 3 & Effect from financial activity & PBT / EBIT \\
\hline 4 & Tax effect & $\mathrm{NP} / \mathrm{PBT}$ \\
\hline 5 & Cash funds management, days & $\mathrm{CF} \times 365 / \mathrm{NS}$ \\
\hline 6 & Receivables management, days & $\mathrm{R} \times 365 / \mathrm{NS}$ \\
\hline 7 & Stock management, days & $\mathrm{S} \times 365 / \mathrm{NS}$ \\
\hline 8 & Other current assets management, days & $\mathrm{INCA} \times 365 / \mathrm{NS}$ \\
\hline 9 & Fixed assets management, days & FA x 365 / NS \\
\hline
\end{tabular}




\begin{tabular}{|c|l|c|}
\hline 10 & Other non-current assets management, days & ONCA x 365/ NS \\
\hline 11 & Debt load & LC / E \\
\hline 12 & Level of interest-free liabilities in the equity & IFL / E \\
\hline
\end{tabular}

Source: Dupont model.

An analysis of the financial structure of the business model for the Canvas elements is possible by the following indicators (see Table 4).

Table 4. Financial structure of the business-model

\begin{tabular}{|c|l|c|}
\hline № & \multicolumn{1}{|c|}{ Business-model elements under Canvas } & ROE decomposition \\
\hline 1 & Key partners and stakeholders & Gross margin, $\%$ \\
\hline 2 & Key activity & Effect from commercial and managerial costs \\
\hline 3 & Value proposition & Effect from financial activity \\
\hline 4 & Customer reationship & Debt load \\
\hline 5 & Customer segment & Stock management, days \\
\hline 6 & Key resources & Other current assets management, days \\
\hline 7 & Channels & Tax effect \\
\hline 8 & Cost structure & Level of interest-free liabilities in the equity \\
\hline 9 & Revenue stream & Cash funds management, days \\
Other non-current assets management, days
\end{tabular}

Source: own development.

The method of decomposition is a tool for evaluating the financial results of the enterprise. However, it does not include non-financial measurements of enterprise development, such as consumer satisfaction, internal business processes, training and growth of the corporation. The figure shows the mutual relationships between elements of the business model and the financial dimensions of ROE.

Factors that may or may hinder the development of the port's business-model are the following (Alderton, 2008):

- changes in the internal transport infrastructure. For example, the development of the railway infrastructure leads to an increase in large ports, and a decrease in the loading of small ones. Motorways, on the contrary, promote the revival and development of small ports. This makes shipowners access to the port better. At the same time, the attraction of large container vessels encourages the growth of large ports.

- changes in trading models related to government trade agreements. Such agreements and regimes should be analyzed in terms of the strategy of attracting ports and the impact on their download.

- changes in financial and logistics considerations. Ports can be considered storage sites and as industrial zones. Recently there are many proposals for the creation of value added ports through their services. Ports can become promising distribution and marketing centers, such as the Habmourg or Bremen (Alderton, 2008).

- the life cycle of the port can approach the infinity, measured for centuries. For this purpose, ports should take into account the trends of modernity and carry out reconstruction and reorganization.

- labor, in particular, an increase in the automation of service processes leads to unemployment and strikes. Necessary strategy of harmonization of robotizing processes.

- exceptional bad weather also damaged many ports, many of which were insured and could not find the necessary capital to repair damage.

- changes in the technology of movement of cargoes requiring necessary investments. In particular, you may need to invest in terminals to find guts after changing the policy of placing goods from pipelines in some areas. 
Indicators that can be considered for improving port management include: reducing the cost of repairs, maintenance and administrative costs; increase of container tonnage; salary increase for staff; shorter downtime of ships in the port; increasing port loading in the form of increasing the number of working hours per day, as well as increasing the speed of handling containers and cargoes.

In accordance with the adapted model of port competitiveness Porter Diamond, competitiveness is a system with elements that mutually reinforce each other in creating industry competitiveness. In this case, the elements are mutually dependent because the state of one affects the state of another. Porter believes that the two final factors that influence success are the chance and the government. Competitive factors are the factors of production itself, more precisely: labor, land, natural resources, capital, and infrastructure. However, the main decisive in the formation of competitive advantages is the technological know-how (see Fig. 4).

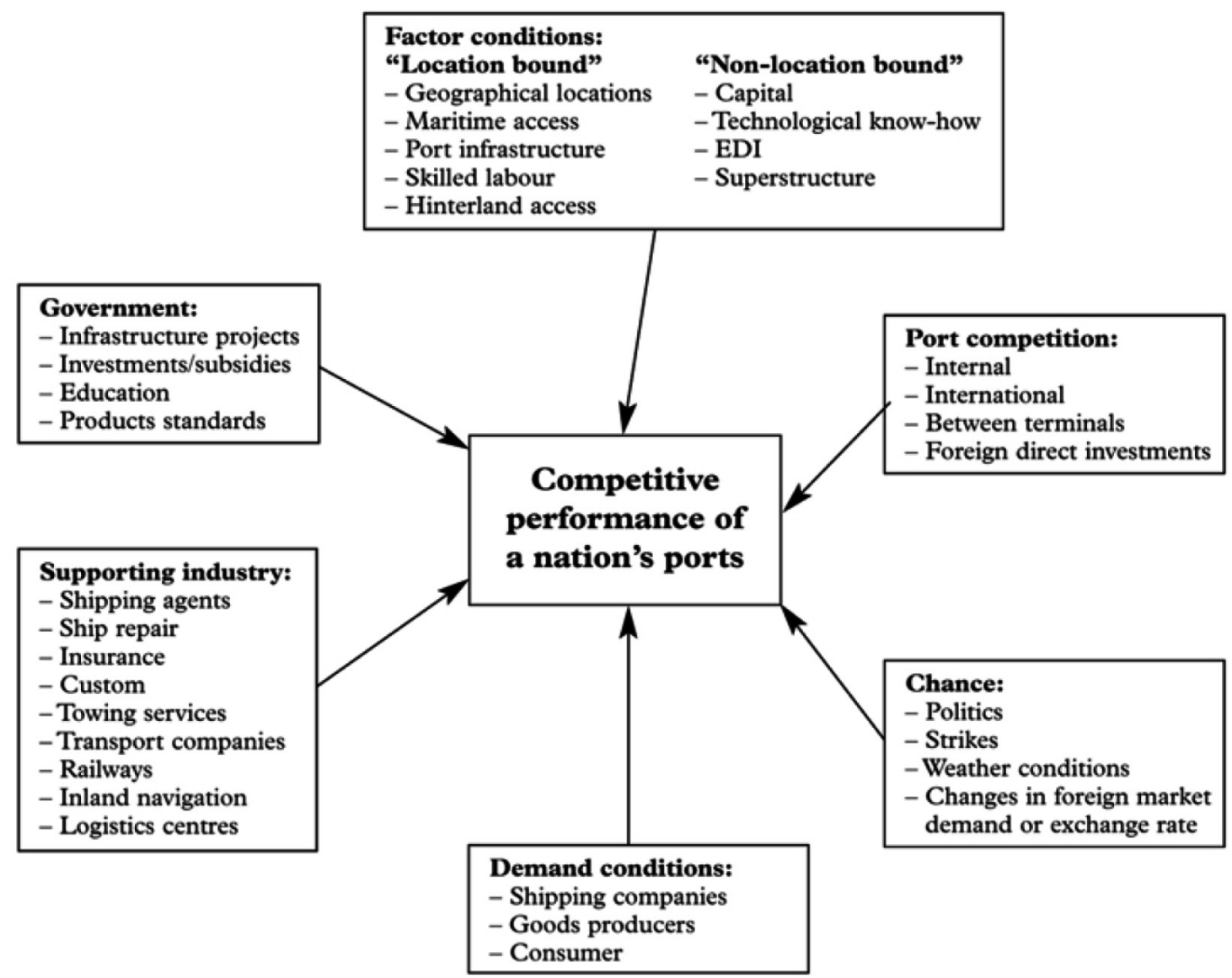

Fig. 4. Model of port competitiveness

Source: Alderton (2008)

A SWOT analysis can be a useful and commonly used analysis tool for assessing port development potential. Its typical elements are (Alderton, 2008):

- maritime accessibility, availability of depth and position on the main trade routes;

- the amount of transhipped cargo that the port can attract, and the capacity for storage;

- logistics, which provides added value and availability to industrial producers;

- activity of transport agencies and distribution networks of goods;

- well-trained labor force and efficient service companies;

- technologies and communication systems;

- the state of internal and external competition;

- presence and influence of port administrations;

- costs. 


\section{Qualitative monitoring of the sea trade port business model}

The correspondence of the sea trade port business-model to the goal 9 from the list of sustainable development goals in order to build resilient infrastructure, promote inclusive and sustainable industrialization and foster innovation should meet the following targets and indicators (see Table 5).

Table 5. Business-model track for correspondence to sustainable development indicators

\begin{tabular}{|l|l|}
\hline \multicolumn{1}{|c|}{ Sustainable Development Target } & \multicolumn{1}{c|}{ Monitoring Indicator } \\
\hline $\begin{array}{l}\text { 1. Develop quality, reliable, sustainable and resilient infrastructure, including regional } \\
\text { and trans-border infrastructure, to support economic development and human well- } \\
\text { being, with a focus on affordable and equitable access for all }\end{array}$ & $\begin{array}{l}\text { 1.1 Share of the rural population who live } \\
\text { within 2 km of an all-season road }\end{array}$ \\
\cline { 2 - 3 } $\begin{array}{l}1.2 \text { Passenger and freight volumes, by mode } \\
\text { of transport }\end{array}$ \\
\hline $\begin{array}{l}\text { 2. Promote inclusive and sustainable industrialization and, by 2030, significantly raise } \\
\text { industry's share of employment and gross domestic product, in line with national } \\
\text { circumstances, and double its share in least developed countries }\end{array}$ & $\begin{array}{l}2.1 \text { Manufacturing value added as a } \\
\text { percentage of GDP and per capita }\end{array}$ \\
\cline { 2 - 3 } $\begin{array}{l}\text { 2.2 Manufacturing employment as a } \\
\text { percentage of total employment }\end{array}$ \\
\hline $\begin{array}{l}\text { 3. Support domestic technology development, research and innovation in developing } \\
\text { countries, including by ensuring a conducive policy environment for, inter alia, } \\
\text { industrial diversification and value addition to commodities }\end{array}$ & $\begin{array}{l}\text { 3.1 Percentage of medium and high-tech } \\
\text { industry value added in total value added }\end{array}$ \\
\hline $\begin{array}{l}\text { 4. Significantly increase access to information and communications technology and } \\
\text { strive to provide universal and affordable access to the Internet in least developed } \\
\text { countries by 2020 }\end{array}$ & $\begin{array}{l}\text { 4.1 Percentage of population covered by } \\
\text { technology }\end{array}$ \\
\hline
\end{tabular}

Source: Report of the Inter-Agency and Expert Group on Sustainable Development Goal Indicators (2016); Balcerzak, (2015); Reznik \& Reznik, (2015)

Qualitative monitoring of modern port business-models may be carried out from the point of view of importers and exporters according to the following criteria for port selection (see Table 6):

Table 6. Qualitative indicators of the sea trade port business-model track

\begin{tabular}{|c|l|c|}
\hline № & Business-model elements under Canvas & Indicator \\
\hline 1 & Key partners and stakeholders & Intermodal links \\
\hline 2 & Key activity & $\begin{array}{r}\text { Tracking systems; container facilities; consolidation services; heavy lift services; } \\
\text { marshalling yards; bulk facilities; cold storage facilities }\end{array}$ \\
\hline 3 & Value proposition & Road and rail services; custom handling; port security; port equipment. \\
\hline 4 & Customer reationship & Number of sailings \\
\hline 5 & Customer segment & Port size, proximity of the port \\
\hline 6 & Key resources & Warehousing \\
\hline 7 & Channels & Logistics forecasting \\
\hline 8 & Cost structure & Interrelation to added value \\
\hline 9 & Revenue stream & Port charges; inland freight rates \\
\hline
\end{tabular}

Source: own development based on Alderton (2008)

Although decision on the choice of port is taken by the consumer himself, his decision is influenced not only by the desire of the suppliers, but also the services offered as substitutes by other modes of transport, except for the sea. Strategic study conducted at Port Rotterdam proved that the most important factors when deciding on the choice of ports are: costs, service and movement of goods. Costs must be competitive and low for freight. The service must be reliable, fast, provide good communication and numerous departures and low traffic congestion. The movement of goods must be effective in terms of association with other modes of transport and intermodal communication. 


\section{Conclusions}

The roadmap for developing a business model consists of: the process of generating a business idea on the components of the business model; the process of evaluating a business idea before its introduction; direct formation of elements of a business model; identification of complementary assets; generating business model innovation in the form of multidimensional innovation; creation of added value in business model.

The port management process is influenced by: local authorities, customers (shippers), pressure groups, trade unions, international norms, trade agreements, shipowners, competition, corruption, government.

The financial structure in which it is possible to monitor the business model is the decomposition of the return on equity.

It is recommended to monitor the business model of the sea trade port on quality indicators by means of correlation with the management tasks of the port in order to improve its competitive positions. The assessment of competitive positions is based on the criteria of port selection (port departure, internal freight rates, proximity of the port, port overload, intermodal connections, port equipment, port charges, customs clearance, port security) and port service criteria (road and rail services, accommodation for containers; systems of tracking; warehousing; consolidation services; heavy lifting services; sorting platforms; the possibility of processing bulk cargoes; storage possibilities in cooling conditions).

On the basis of conducted theoretical research we identify the perspective direction of the business-model sustainable development depending on the ownership and management structure based on the multidimensional innovation generation with the value added source and complementary assets basis for thesea commercial port (see Table 6).

Table 6. Business-model sustainable development for the sea commercial port

\begin{tabular}{|c|c|c|c|c|}
\hline \multirow{2}{*}{ № } & \multirow{2}{*}{ Port characteristics } & \multicolumn{3}{|c|}{ Port type } \\
\hline & & Landlord & Instrumental port & Service port \\
\hline 1 & Market innovation & tax windows & $\begin{array}{l}\text { replacement of the crew of } \\
\text { the vessels }\end{array}$ & $\begin{array}{l}\text { cruises and yachting } \\
\text { services }\end{array}$ \\
\hline 2 & Product innovation & organization of excursions to the port & $\begin{array}{l}\text { the speed of cargo handling } \\
\text { and the documentation in } \\
\text { terms of cost minimization }\end{array}$ & $\begin{array}{l}\text { delivery of a sea pilot to a } \\
\text { vessel from a helicopter or } \\
\text { a boat }\end{array}$ \\
\hline 3 & $\begin{array}{l}\text { Business-model } \\
\text { innovation (process } \\
\text { innovation) }\end{array}$ & $\begin{array}{l}\text { redistribution of energy resources at the port } \\
\text { entrance }\end{array}$ & hub model for port & $\begin{array}{l}\text { conducting environmental } \\
\text { audit }\end{array}$ \\
\hline 4 & $\begin{array}{l}\text { Budget-generating } \\
\text { port service } \\
\text { (value added } \\
\text { generation) }\end{array}$ & $\begin{array}{l}\text { vessels traffic service, the provision of } \\
\text { emergency and rescue works, navigational } \\
\text { and hydrographic and mapping of navigation, } \\
\text { ensuring prevention and elimination of } \\
\text { pollution of contaminated substances }\end{array}$ & $\begin{array}{l}\text { carrying out cargo } \\
\text { operations, including } \\
\text { carrying out loading and } \\
\text { unloading operations }\end{array}$ & $\begin{array}{l}\text { service of ships and } \\
\text { passengers }\end{array}$ \\
\hline 5 & $\begin{array}{l}\text { Priority of } \\
\text { management aim }\end{array}$ & $\begin{array}{l}\text { the increase of paid taxes, the level of } \\
\text { employment of the population }\end{array}$ & increase in cargo turnover & $\begin{array}{l}\text { improving the quality } \\
\text { of transport services, } \\
\text { increasing the number of } \\
\text { tourists. }\end{array}$ \\
\hline
\end{tabular}

Source: own development.

The targets of the sustainable development Goal 9. "Build resilient infrastructure, promote inclusive and sustainable industrialization and foster innovation" for the sea commercial ports should be aheived throough the business-model construction and be in progress as follows:

1. Develop quality, reliable, sustainable and resilient infrastructure, including regional and trans-border infrastructure, to support economic development and human well-being, with a focus on affordable and equitable access for all covered by product innovation. 
2. Promote inclusive and sustainable industrialization and, by 2030, significantly raise industry's share of employment and gross domestic product, in line with national circumstances, and double its share in least developed countries covered by budget-generating port service (value added generation).

3. Support domestic technology development, research and innovation in developing countries, including by ensuring a conducive policy environment for, inter alia, industrial diversification and value addition to commodities covered by market innovation.

4. Significantly increase access to information and communications technology and strive to provide universal and affordable access to the Internet in least developed countries by 2020 covered by business-model innovation (process innovation).

\section{References}

Abuzyarova, M. (2015). The complementarily of companies' assets as an effective tool for managing innovation projects. London Journals in Economics, Marketing, Finance, Business and Innovation, 2, 7-17.

Alderton, P. (2008). Port Management and Operations. London: Published by Informa.

Balcerzak, A. P. (2015). Europe 2020 strategy and structural diversity between old and new member states. application of zero unitarization method for dynamic analysis in the years 2004-2013. Economics \& Sociology, 8(2), 190-210

Batocchio, A., \& Minatogawa, V. (2017). Proposal for a method for business model performance assessment: towards an experimentation tool for business model, Journal of Technology Management and Innovation, 12 (1), 61-70.

Bereznoy, A. (2014). Innovative business-model in competitive strategy of the big company, Issues of Economy, 9, 65-81.

Bilan, Y. (2013). Sustainable Development of a Company: Building of New Level Relationship with the Consumers of XXI Century. Amfiteatru Economic, 15, 687-701.

Bossidi, L., \& Charan, R. (2007). Facing to reality. How to adapt business-model to changing environment. Moscow: Published byWilliams.

Buyanov, D. (2014). Theory of the transaction costs and complementary assets as theoretical platforms fot building the outsourcing model, Herald of the Omsk University, 2, 160-165.

Chesbrough, G. 2007. Open innovations. Creation of the profitable technologies. Moscow: Published by Generation.

Čirjevskis, A. (2017). Acquisition based dynamic capabilities and reinvention of business models: bridging two perspectives together. Entrepreneurship and Sustainability Issues, 4 (4), 516-525. https://doi.org/10.9770/jesi.2017.4.4(9)

Czyżewski, A., \& Smędzik-Ambroży, K. (2015). Specialization and diversification of agricultural production in the light of sustainable development. Journal of International Studies Vol, 8(2), 63-73.

Debelak, D. (2006). Business models made easy. California: Published by Entrepreneur Press.

Dolzhenkova, E., \& Kazakova, M. (2015). Complementary and synergic approach to the innovative development of the social-economic systems, Economy and entrepreneurship, 2, 559-563.

Hilkevics, S.; Hilkevics, A. (2017). The comparative analysis of technology transfer models. Entrepreneurship and Sustainability Issues 4(4), 540-558. https://doi.org/10.9770/jesi.2017.4.4(11)

Kim, W. Chan, \& Renee, A. Mauborgne. (2014). Blue ocean strategy, expanded edition: How to create uncontested market space and make the competition irrelevant. Published by Harvard business review Press.

Mukhtarova, K. S., Trifilova, A. A., \& Zhidebekkyzy, A. (2016). Commercialization of Green Technologies: an Exploratory Literature Review. Journal of International Studies, 9(3), 75-87.

Osterwalder, A., \& Pigneur, Y. (2010). Business model generation: a handbook for visionaries, game changers, and challengers. New jersey: Published by John Wiley \& Sons.

Pastor-Agustín, G., Marisa Ramírez-Alesón, M., \& Espitia-Escuer, M. (2011). Complementary Assets and Investment Decisions. Emerging Markets Finance \& Trade, 47, Supplement, 5, 25-39. 
Pek-Hooi, S., \& Jiang, Y. (2010). Institutional environment and complementary assets: Business strategy in China's 3G development, Asia Pacific Journal of Management, 12, 646-675.

Progress towards the Sustainable Development Goals Report of the Secretary-General. Economic and Social Council of the United Nations No. 75, 2016. Available at: https://unstats.un.org/sdgs/files/report/2016/secretary-general-sdg-report-2016--EN.pdf

Report of the Inter-Agency and Expert Group on Sustainable Development Goal Indicators. Economic and Social Council of the United Nations No. 3, Rev. 1, 2016. Available at: http://undocs.org/en/E/CN.3/2016/2/Rev.1

Reznik, V., \& Reznik, O. (2015). Social Legitimation of Capitalism in Ukraine: from Socio-cultural Path-dependence to Rationalization of Economic Situation. Economics \& Sociology, 8(3), 131.

Rothaermel, F.T. (2001). Complementary assets, strategic alliances, and the incumbent's advantage: An empirical study of industry and firm effects in the biopharmaceutical industry, Research Policy, 30, 1235-1251.

Rothaermel, Frank T., \& Hill, Charles W.L. (2005). Technological Discontinuities and Complementary Assets: A Longitudinal Study of Industry and Firm Performance, Organization Science, 16(1), 52-70.

Schweizer, L. (2005). Concept and evolution of business models, Journal of General Management, 31(2), 37-56.

Simionescu, M., Albu, L. L., Szeles, M. R., \& Bilan, Y. (2017). The Impact of Biofuels Utilisation in Transport on the Sustainable Development in the European Union. Technological and Economic Development of Economy, 23(4), 667-686. https://doi.org/10.3846/2 0294913.2017.1323318

Slywotzky, A.J. (2006). Value Migration what will happen to your business the day after tomorrow. Translated from English Moscow: Published by Ivan, Mann, Ferber.

Slywotzky, A.J. et al. (1999). Profit patterns. New York: Published by Times Business.

Soolyatte, A. (2010). Business-model - a key to business development, based on innovations, Innovation Management, 1(9), 6-15.

Streimikiene, D., Strielkowski, W., Bilan, Y., \& Mikalauskas, I. (2016). Energy dependency and sustainable regional development in the Baltic States - a review. Geographica Pannonica, 20(2), 79-87.

Tripsas, M. (1997). Unraveling the process of creative destruction: Complementary assets and incumbent survival in the typesetter industry, Strategic Management Journal, 18, 119-142.

Tvaronavičienè, M.; Černevičiūtè, J. (2015). Technology transfer phenomenon and its impact on sustainable development. Journal of Security and Sustainability Issues 5(1), 87-97. DOI: http://dx.doi.org/10.9770/jssi.2015.5.1(7)

Urbaniec, M. (2015). Towards Sustainable Development through Eco-innovations: Drivers and Barriers in Poland. Economics \& Sociology, 8(4), 179-190.

Vashakmadze, T. (2012). The comparative analysis of the enterprise business-models, Economy and Life, 16(45), 35-45.

Vleugels, R.L.M. (1969). The Economic Impact of Ports on the Regions they serve and the Role of Industrial Development. Published by the International Association of Ports and Harbors.

Zott, C., Amit, R., \& Massa, L. (2011). The business model: recent developments and future research, Journal of management, 37(4), 1019-1042. 